\title{
PENGENAAN MANUSIA BARU DI DALAM \\ KRISTUS: NATUR, PROSES, DAN FAKTA SERTA IMPLIKASI TEOLOGIS DAN PRAKTISNYA
}

\author{
Hengki Wijaya ${ }^{1)^{*}}$ \\ 1) Dosen Teologi Sekolah Tinggi Theologia Jaffray \\ ${ }^{*}$ Penulis korespondensi: hengkiwijaya@sttjaffray.ac.id
}

\begin{abstract}
Abstrak
Natur orang percaya menjadi manusia baru adalah sekali untuk selamalamanya, namun proses untuk menjadi manusia baru adalah peristiwa yang terus-menerus diperbarui untuk serupa dengan gambar-Nya yang sesuai dengan kehendak-Nya. Faktanya orang percaya memiliki status manusia baru yang menjalani kehidupan manusia baru. Implikasi teologis pengenaan manusia baru dalam Kristus adalah orang percaya terus-menerus diperbarui oleh Roh Kudus untuk menjadi ciptaan yang baru yang serupa dengan gambar-Nya.Roh Kudus memeteraikan orang percaya dan mengerjakan keselamatan orang percaya menjadi manusia baru. Implikasi praktis pengenaan manusia baru dalam Kristus adalah tanggung jawab orang percaya yang memahami status baru di dalam Kristus untuk menyatakan kebenaran, menjadi berkat bagi orang lain, menyenangkan Roh Kudus dan mengenakan kasih di dalam Kristus.

Kata-kata kunci: natur, teologis, praktis, pengenaan, manusia baru, Efesus, Kristus.

The status of a believer becoming a new man is a once for all event, but the process of becoming the new man is continually renewed to become similar to the image of God and in accordance with His will. There are people who believe that the status of the new man undergoes a new human life. The theological implications of the putting on of the new man in Christ is that the believer is continuously renewed by the Holy Spirit to become a new creature in His image. The Holy Spirit seals believers and works to bring them into this new man. The practical implications of this putting on of the new man in Christ are the responsibilities of the new believer who understands his new status in Christ, to proclaim the truth, be a blessing to others, forgiving and loving others by the Holy Spirit in Christ.
\end{abstract}

Keywords: nature, theological, practical, put on, new man, Ephesians, Christ.

\section{Pendahuluan}

Orang Kristen yang telah meninggalkan dosanya, yaitu menanggalkan manusia lamanya serta kelakukannya dan telah mengenakan manusia baru yang terus-menerus diperbarui (Efesus 4:2324; Kolose 3:9-10) di dalam Kristus. 
Richard L. Pratt berpendapat bahwa orang-orang yang percaya dalam Kristus diperbarui secara terus-menerus menurut sifat mereka yang semula sebagai manusia yang diciptakan menurut gambar dan rupa Allah. Mereka diberikan kebenaran, kesucian, dan pengetahuan yang benar, di mana semua itu telah hilang pada waktu kejatuhan. Manusia tidak diselamatkan untuk sekadar berada dalam keadaan yang manis dan menyenangkan. Namun, manusia diperbarui sebagai ciptaan baru dan dikembalikan kepada asal mula keberadaan manusia sebagai gambar Allah melalui kelahiran baru. ${ }^{1}$ Inilah janji firman Tuhan bagi mereka yang percaya dan mengaku dalam hati bahwa Yesus adalah Tuhan dan Juruselamat. Dan bagi setiap pribadi yang telah menerima Yesus Kristus sebagai Tuhan dan Juruselamat, harus mengenakan manusia baru yang telah diciptakan menurut kehendak Allah di dalam kebenaran dan kekudusan yang sesungguhnya dan meninggalkan dosa atau kehidupan lama yang tidak memuliakan Allah, sehingga dapat disebut sebagai murid Kristus sejati dan dapat menyatakan kehidupan Kristus bagi dunia lewat praktik kehidupannya.

Pandangan Sinclair B. Ferguson berkata bahwa orang yang telah menerima Kristus dan percaya kepada-Nya harus sungguh-sungguh membenci dosa, berpaling dari dosa kepada Allah, dan memiliki kesungguhan hati untuk taat kepada Allah. ${ }^{2}$ Apakah pernyataan ini sungguh-sungguh dialamai oleh orang percaya ataukah justru mereka terus-menerus bergumul dengan jatuh bangun dengan dosa?

Kenyataannya ini juga terjadi pada gereja yang hidup di dalam kesenangan dosa dan tidak sungguh-sungguh hidup sebagai ciptaan baru di dalam Kristus. Tidak dapat disangsikan bahwa masih banyak orang Kristen yang belum sungguh-sungguh meninggalkan kehidupan yang lama yaitu kehidupan yang penuh dengan dosa dan tidak mengenakan kehidupan yang baru di dalam Kristus.

Paulus mengontraskan manusia lama yang dihubungkan dengan kehidupan berdosa dengan manusia baru yang telah dikenakan, karena sekarang orang percaya telah berada di dalam Kristus. Berkenaan dengan pertanyaan mengenai hubungan antara dua diri atau natur manusia ini, para teolog Reformed memiliki pandangan yang berbeda. Sebagian besar pandangan teolog Reformed, berpegang bahwa manusia lama dan baru adalah aspek-aspek dari orang percaya yang bisa dibedakan. Sebelum konversi, orang-orang percaya hanya memiliki satu manusia yang lama; akan tetapi di saat konversi mereka mengenakan manusia baru tetapi belum menghilangkan manusia yang lama secara total. Menurut

\footnotetext{
${ }^{1}$ Richard L. Pratt, Menaklukkan Segala Pikiran Kepada Kristus (Malang: Seminari Alkitab Asia Tenggara, 2003), 57-58.

${ }^{2}$ Sinclair B. Ferguson, Kehidupan Kekristenan Sebuah Pengantar Doktrinal (Surabaya: Penerbit Momentum, 2007), 97.
} 
pandangan ini, orang Kristen dipahami terdiri dari sebagian manusia baru dan sebagian manusia lama. Terkadang manusia lama ini yang berkuasa, tetapi di waktu-waktu lain manusia baru ini yang memegang kendali; pergumulan hidup menurut pandangan ini adalah pergumulan antara kedua aspek dari keberadaan orang percaya ini. ${ }^{3}$

John Murray menyatakan pengertian manusia lama dan manusia baru dengan baik.

Manusia lama adalah manusia yang belum diregenerasikan; manusia baru adalah manusia yang telah diregenerasikan, yang diciptakan di dalam Kristus Yesus untuk melakukan perbuatan-perbuatan baik. Adalah tidak benar untuk menyebut orang percaya sebagai manusia baru dan manusia lama, itu sama halnya dengan menyebutnya manusia yang telah diregenerasikan sekaligus manusia yang belum diregenerasikan. Dan juga tidak benar untuk mengatakan bahwa di dalam diri orang percaya terdapat manusia lama dan manusia baru. Pemikiran seperti ini tidak memiliki dasar kebenarannya dan ini hanyalah suatu bentuk prasangka terhadap doktrin yang begitu gigih ditegakkan oleh Paulus ketika dia berkata, "Manusia lama telah disalibkan." ${ }^{4}$

Pandangan di atas tentunya menyatakan bahwa orang percaya kepada Yesus adalah manusia baru dan tidak lagi disebut sebagai manusia lama. Sebagai manusia baru, apakah orang percaya di dalam Kristus adalah sungguh-sungguh memiliki status/natur manusia baru ataukah suatu proses dalam kehidupan Kristen? Ataukah juga merupakan fakta bahwa orang percaya dalam Kristus adalah manusia baru yang tidak mungkin menjadi manusia lama lagi?

\section{Konteks Mengenakan Manusia Baru}

\section{Menanggalkan Manusia Lama dan Mengenakan Manusia Baru}

Firman Tuhan dalam Efesus 4:22-24, secara struktur setiap ayat memiliki tiga infinitif. Kata "menanggalkan" dan "mengenakan" adalah bentuk kata kerja aorist middle infinitive, berarti kejadian yang telah terjadi sekali dan kata "dibarui" adalah bentuk kata kerja present middle infinitive, yang terjadi saat sekarang. Ketiga kata ini menjadi inti pengajaran Paulus bagi jemaat di Efesus. Frasa dalam bahasa Yunani palaion anthrôpon yaitu manusia yang penuh dengan dosa yang merupakan warisan dari Adam

\footnotetext{
${ }^{3}$ Anthony A. Hoekema, Diselamatkan Oleh Anugerah (Surabaya: Penerbit Momentum, 2010), 291.

4 John Murray, Principle of Conduct (Grand Rapids: Eerdmans, 1957), 218. Dikutip oleh Anthony A. Hoekema, Diselamatkan Oleh Anugerah (Surabaya: Penerbit Momentum, 2010), 283.
} 
yang cenderung melakukan kejahatan atau old evil nature ${ }^{5}$ yaitu keadaan manusia yang penuh dengan dosa, manusia yang dalam dirinya terdapat segala sesuatu yang duniawi yaitu percabulan, kenajisan, hawa nafsu, nafsu jahat, keserakahan, penyambahan berhala, amarah, geram, kejahatan, fitnah, kata-kata kotor.

Maksud Paulus adalah kamu harus berhenti melakukan dosa karena tindakan dosa tidak konsisten dengan pengenaan manusia barumu. Dan ungkapan yang digunakan Paulus memperkuat pemikiran ini: tidak ada orang yang memakai dua jenis pakaian pada saat yang sama. Orang harus menanggalkan yang satu untuk bisa mengenakan yang lainnya. Paulus di sini menggambarkan orang-orang percaya sebagai umat yang sekarang mengenakan manusia baru dan tidak lagi mengenakan manusia lama. ${ }^{7}$

Konteks menanggalkan manusia lama dan mengenakan manusia baru digambarkan sebagai penanggalan dan pengenaan pakaian yang umum dalam dunia kuno yang dikaitkan dengan tindakan inisiasi. Pengenaan pakaian meneguhkan inisiasi sehingga dia dipenuhi dengan kuasa kosmos dan mendapat bagian dalam kehidupan ilahi. ${ }^{8}$ Orang percaya telah menanggalkan jati dirinya yang lama, yaitu kemanusiaan yang telah jatuh dan takluk di bawah kuk dosa, lalu ia menerima dan mengenakan jati diri yang baru. Paulus menyebut keduanya, "manusia" di mana manusia lama yang ditanggalkan, dan manusia baru yang dikenakan. ${ }^{9}$

Pertanyaan yang harus dijawab adalah "Apakah manusia lama tetap ada setelah mengalami perubahan menjadi manusia baru? atau apakah orang percaya sekaligus "manusia lama" dan "manusia baru?" Apakah manusia baru adalah natur (status), proses menuju manusia baru atau fakta menyatakan orang percaya adalah manusia baru?

\section{Manusia Baru sebagai Natur}

Penting untuk dicatat bahwa makna natur (sifat) sepertinya digunakan dalam perdebatan mengenai satu atau dua natur dalam orang percaya terutama masalah teologis, bukan salah satu dari penggunaan kitab suci. Baik Alkitab KJV maupun NASB, pernah menggunakan

${ }^{5}$ Ruth Paxon, The Wealth Walk and Warfare of The Christian (United Stated of Amerika: Fleming H. Revell Company, 1989), 107; Darius dan Robi Panggarra, "Konsep Manusia Baru Berdasarkan Perspektif Paulus Dalam Efesus 4:17-32 Dan Implementasinya Dalam Kehidupan Orang Percaya," Jurnal Jaffray 11, no. 2 (Oktober 2013).

J. L. Ch. Abineno, Tafsiran Alkitab Surat Efesus (Jakarta: BPK Gunung Mulia, 2009), 154; bandingkan dengan Kolose 3:5, 8.

${ }^{7}$ Hoekema, 293.

${ }^{8}$ Peter Thomas O’Brien, Surat Efesus (Surabaya: Penerbit Momentum, 2013), 401.

${ }^{9}$ John R. W. Stott, Efesus (Jakarta:Yayasan Komunikasi Bina Kasih, 2003), 175. 
istilah natur lama, dosa warisan, atau natur baru. ${ }^{10}$ Beberapa teolog Reformed juga mengatakan bahwa manusia lama dihilangkan pada saat menerima keselamatan, tetapi karena mereka yakin orang percaya hanya memiliki satu natur (sifat) yaitu sifat baru, mereka terpaksa untuk mengatakan bahwa sifat lama dihilangkan juga. Charles Smith mencatat bahwa posisi ini adalah lemah karena tampaknya bergerak menuju pandangan Wesleyan perfeksionisme. ${ }^{11}$ Pendapat yang sama dikemukakan oleh Chafer yang menjawab pertanyaan "apakah manusia lama tetap ada setelah perubahan?" Dengan memenuhi syarat maka jawabannya adalah ya, bahwa manusia lama tetap ada dalam orang percaya. Secara khusus, ia berpendapat bahwa manusia lama itu hilang, namun pada saat yang sama manusia lama itu juga hadir: "tergantung posisi 'manusia lama' telah ditanggalkan selama-lamanya. Secara nyata, 'manusia lama' tetap ada sebagai kekuatan aktif dalam kehidupan yang dapat dikontrol hanya oleh kuasa Allah. ${ }^{12}$

Manusia baru sebagai natur baru yaitu memiliki status manusia baru. Orang percaya menanggalkan pakaian lamanya (manusia lama) dan mengenakan pakaian baru (manusia baru). Menanggalkan jubah kematian dan mengenakan jubah kehidupan yaitu di dalam Kristus. Di dalam Kristus, semua orang percaya memiliki natur (sifat) yang baru.

\section{Manusia Baru adalah Sebuah Proses}

"Apakah manusia lama tetap ada setelah mengalami perubahan menjadi manusia baru?" yang satu adalah "tidak," dan yang lain adalah memenuhi syarat "ya." Showers, dengan tegas mengatakan tidak:

Telah dicatat bahwa 'manusia lama' adalah pribadi manusia dilihat secara etis di dalam status belum dilahirkan yang ditandai dengan posisi budak di bawah watak berdosa dan dengan cara hidup yang berdosa. Hasil identifikasi seseorang yang mengalami kematian bersama Kristus, ia berhenti menjadi 'manusia lama' yang mati secara etis dalam arti bahwa ia berhenti menjadi orang yang belum dilahirkan yang ditandai dengan posisi budak di bawah watak berdosa dan oleh cara hidup berdosa. ${ }^{13}$

\footnotetext{
${ }^{10}$ William W. Combs, "Does The Believer Have One Nature Or Two?" Detroit Baptist Seminary Journal 2 (Fall 1997): 81-103.

${ }^{11}$ Charles R. Smith, "Two Natures-Or One? An Attempt at Theological Clarification." Voice (Juli/Agustus 1983): 21.

${ }^{12}$ Lewis Sperry Chafer, He That Is Spiritual (Grand Rapids: Zondervan, 1967), 113; Lewis Sperry Chafer, Systematic Theology (Grand Rapids: Kregel, 1993), 348.

13 Renald Showers, "The New Nature," Th.D. dissertation (Grace Theological Seminary, 1975), 225; Leon Morris, The Epistle to the Romans in The Pillar New Testament Commentary (Grand Rapids: Eerdmans, 1988), 251.
} 
Showers mendukung perbedaan antara manusia lama dan sifat lama (natur lama). Dengan demikian, hal itu bukan masalah baginya untuk mengatakan bahwa manusia lama dihilangkan sementara orang percaya masih berjuang dengan dosa, karena sifat lama masih berlanjut. Morris berpendapat bahwa manusia lama itu berlanjut, dengan mengatakan bahwa "ada rasa di mana kematian telah terjadi sekali ... tetapi ada hal lain di mana manusia lama itu mati setiap hari." "Jawaban lainnya, pada waktu transformasi manusia lama itu adalah bahwa manusia lama akan dihapus secara bertahap, sebagai bagian dari proses pengudusan. Louis Berkhof mengatakan bahwa "Sisi negatif pengudusan terdiri di dalam hal ini bahwa kecemaran dan korupsi natur manusia asasi yang dihasilkan dari dosa secara bertahap dihapus. Manusia lama yaitu sifat manusia sejauh itu dikendalikan oleh dosa, secara bertahap disalibkan (Roma 6:6; Galatia 5:24). ${ }^{15}$

Smith memberikan ringkasan dari beberapa pandangan, seperti yang telah diuraikan di atas: ${ }^{16}$

1. Natur lama berbeda dengan manusia lama

a. Natur lama diganti oleh natur baru dan manusia lama digantikan oleh manusia baru.

b. Natur lama berlanjut dan manusia lama digantikan oleh manusia baru dan natur baru yang ditambahkan.

2. Natur lama identik dengan manusia lama. Natur lama/manusia lama masih berlanjut setelah keselamatan dan natur baru/manusia baru ditambahkan.

Penjelasan natur lama berlanjut dan manusia lama digantikan oleh manusia baru dan natur baru yang ditambahkan. Hoekema berpendapat bahwa orang percaya di dalam Kristus, bukan lagi manusia lama, tetapi sekarang adalah manusia baru. Di dalam regenerasi orang percaya menerima suatu natur baru sebagai tambahan bagi natur lama, yang mana dengan natur baru ini, dia dimampukan untuk melakukan yang berkenan kepada Allah. Maka orang-orang percaya memang memiliki natur berdosa (yang harus mereka perangi dalam pergumulan) dan natur baru (yang berdasarkan ini mereka harus menjalani hidup mereka). Orang-orang percaya bukan lagi merupakan manusia lama yang secara total diperbudak oleh dosa, melainkan manusia baru yang secara total dikendalikan oleh Roh Kudus (walaupun belum secara sempurna). Dengan kata lain, orang percaya adalah pribadi-pribadi baru yang masih

\footnotetext{
${ }^{14}$ Leon Morris, The Epistle to the Romans in The Pillar New Testament Commentary (Grand Rapids: Eerdmans, 1988), 251.

${ }^{15}$ Louis Berkhof, Manual of Christian Doctrine (Grand Rapids: Eerdmans, 1933), 268.

${ }^{16}$ Charles Smith, "Two Natures-Or One? An Attempt at Theological Clarification," 20.
} 
bergumul melawan natur lama mereka. ${ }^{17}$ Manusia baru adalah sebuah proses yang harus dijalani oleh orang percaya setelah menerima natur baru setelah menerima keselamatan oleh Kristus. Sekali untuk selamanya menerima natur baru, namun proses menjalani manusia baru adalah sebuah proses terus-menerus oleh Roh Kudus menjadi manusia baru.

\section{Manusia Baru adalah Fakta?}

Manusia baru adalah fakta bila orang percaya mengakui statusnya sebagai manusia baru dan melakukan perbuatannya sebagai manusia baru melalui pertolongan Roh Kudus yang terus-menerus memperbarui pikiran orang percaya dan orang percaya hidup sebagai manusia baruciptaan baru dalam Kristus. Orang percaya tidak boleh lagi terus hidup seperti orang-orang yang belum percaya (Ef. 4:17-19), karena seperti yang telah diajarkan, orang percaya telah mengenakan manusia baru yang diciptakan serupa dengan Allah dalam kebenaran dan kekudusan. ${ }^{18}$

Ajaran Perjanjian Baru konsisten mengenai aspek definitif dari pengudusan yaitu orang-orang percaya bukan lagi merupakan manusiamanusia lama seperti keadaan yang dahulu. Orang-orang percaya bukan sekaligus manusia lama dan manusia baru, tetapi benar-benar manusia baru di dalam Kristus. ${ }^{19}$ Pengudusan definitif adalah peristiwa pengudusan yang terjadi sekali dalam kehidupan orang percaya, namun melanjutkan dampak yang dihasilkan dari pemutusan dari manusia lama untuk menghidupi manusia baru di dalam Kristus. ${ }^{20}$ Berdasarkan penjelasan dapat disimpulkan bahwa menjadi manusia baru di dalam Kristus adalah fakta. Berarti orang percaya sungguh-sungguh menjadi manusia baru oleh pertolongan Roh Kudus yang diwujudnyatakan dalam tindakan sebagai ciptaan baru.

\section{Implikasi Teologis Manusia Baru Di Dalam Kristus}

\section{Pembaruan Pikiran}

Gambaran yang kontras antara manusia lama dan manusia baru yang orang percaya kenakan ada ayat 23 yaitu supaya kamu dibarui. Orangorang percaya diajarkan bukan hanya untuk menanggalkan manusia lama dengan cara-cara yang menyesatkan dan mengenakan manusia baru; orang-orang percaya juga diajarkan bahwa orang-orang percaya

\footnotetext{
${ }^{17}$ Hoekema, 297-298.

${ }^{18}$ Hoekema, 282. Perhatikan bahwa baik surat Kolose 3:9-10 maupun surat Efesus 4:22-24 meneguhkan pola yang telah dikembangkan sebelumnya, yaitu pola pengudusan adalah keserupaan dengan Allah.

${ }^{19}$ Hoekema, 282-283.

${ }^{20}$ Peter Thomas O’Brien, Surat Efesus, 400-401.
} 
dipanggil untuk pembaruan batin. Untuk menggambarkan menanggalkan manusia lama (4:22) dan mengenakan manusia baru (4:24). Paulus menggunakan dua infinitif aorist. Paulus menggambarkan masing-masing tindakan sebagai suatu keutuhan yang komplit atau tidak dapat dibedakan. ${ }^{21}$ Dalam Kolose 3:10, orang percaya telah mengenakan manusia baru ketika menanggalkan manusia lama di amsa lalu dan sekarang terus-menerus dibarui dengan pengetahuan yang benar sesuai dengan standar Allah. ${ }^{22}$

Pembaruan batin dalam hal sikap orang percaya (4:23) digambarkan oleh Paulus sebagai suatu proses. Allah adalah Pribadi yang mengadakan pekerjaan pembaruan yang terus-menerus pada umat-Nya. Pada saat yang sama, nasihat implisit menekankan gagasan suatu tantangan terusmenerus untuk orang percaya. Ketika orang-orang percaya diajar dalam Kristus maka didorong untuk diperbarui. Orang percaya harus menyerahkan diri kepada Allah dan membiarkan diri diperbarui dalam manusia batinnya. ${ }^{23}$

\section{Persatuan di dalam Kristus}

Frasa "di dalam Kristus" terdapat dalam Efesus 4:2l, yang ditujukan kepada pribadi Yesus yaitu "di dalam Dia." Pada bagian lain surat Efesus terdapat frasa tersebut yaitu Paulus mengatakan "di dalam Kristus", karena di dalam Dialah kami mendapat bagian yang dijanjikan (Ef. 1:1l; bdg. 2:15; 3:5, 12).

Pandangan Paulus tentang kesatuan dengan Kristus terlihat jelas dalam pasal 4 surat Efesus. Persatuan dengan Kristus sering kali digambarkan sebagai keberadaan "di dalam Kristus," Paulus menyebut pembaca-pembacanya "orang-orang kudus," orang-orang yang dipisahkan oleh dan bagi Allah. Ekspresi-ekspresi ini menunjukkan kedekatan ikatan antara Allah dan umat-Nya. ${ }^{24}$ Frasa "di dalam Dia" (Ef. 4:21) menjelaskan bahwa orang percaya hanya dapat hidup kudus di dalam Dia. Dia adalah Kepala dan orang percaya adalah tubuh Kristus yang harus bertumbuh di dalam segala hal ke arah Dia, Kristus (Ef. 4:15).

Persatuan dengan Kristus merupakan dasar dari semua pengalaman rohani yang diberikan kepada orang percaya "di dalam Kristus," dan

\footnotetext{
${ }^{21}$ O'Brien, 403.

${ }^{22}$ Lance T. Beauchamp, "The Old and New Man in Ephesians 4:17-24," (Faculty Publications and Presentations, 2007), 41, diakses 12 Desember 2013,

http://digitalcommons.liberty.edu/sor_fac_pubs/179.

${ }^{23}$ O'Brien, 403-404.

${ }^{24}$ Sinclair B. Ferguson, Kehidupan Kristen Sebuah Pengantar Doktrinal (Surabaya: Penerbit Momentum, 2007), 138. Penyebutan “di dalam Kristus" bervariasi (bdg. Ef. 1:1; 1 Kor. 1:2; Flp. 1:1; Kol. 1:2; 1 Tes. 1:1; 2 Tes. 1:1). Sejajar dengan ini adalah penekanan yang lain yaitu Kristus ada "di dalam” orang percaya (bdg. Rm. 8:10; Gal. 2:20; Kol. 1:27).
} 
hanya mereka yang ada "di dalam Kristus" yang bisa mengalaminya. Paulus menekankan hal ini khususnya di Efesus 1:3-14. Orang percaya telah diberkati di dalam Kristus, kata Paulus, sebagaimana telah dipilih (ayat 4), dianugerahi (ayat 6), ditebus (ayat 7), diperdamaikan (ayat 10), ditetapkan (ayat 11) dan dimeteraikan (ayat 13) di dalam Kristus. Kehidupan orang percaya dari awal sampai akhir merupakan kehidupan yang berpusat pada Kristus dan terus-menerus memandang kepada-Nya untuk semua pemenuhan rohani yang dibutuhkan. ${ }^{25}$ Penjelasan menanggalkan manusia lama dan mengenakan manusia baru berarti meninggalkan masa lalu (dosa) dan memandang kepada Kristus dan hidup kudus di dalam Kristus. Di dalam Kristus, orang percaya mendapatkan berkat rohani yang Allah sediakan baginya.

Ungkapan "di dalam Kristus" adalah salah satu rumusan Paulus yang paling khas. Deismann mengemukakan pengertian teologis ungkapan ini dengan menekankan pada dimensi mistisnya yaitu persekutuan mistis yaitu persekutuan dengan Dia. ${ }^{26}$ Orang yang tidak mengenal Allah dan hidup tidak kudus adalah orang yang jauh dari hidup persekutuan dengan Allah (Ef. 4:18), tidaklah demikian orang percaya yang hidup kudus berarti hidup di dalam Kristus dan memiliki hubungan dengan Kristus Yesus.

Paulus menekankan kekudusan pada setiap kehidupan pembacanya. Paulus mengatakan kepada mereka bahwa tujuan pemilihan adalah supaya mereka kudus dan tak bercacat di dalam Dia (Ef 1:4), dan di dalam Dia tumbuh seluruh bangunan, rapi tersusun, menjadi bait Allah yang kudus, di dalam Tuhan (Ef. 2:21), dan mereka telah mengenakan manusia baru yang ditandai dengan kekudusan (4:24). Tujuan pengorbanan kematian Kristus adalah pengudusan mempelai-Nya, gereja-Nya sesudah Ia menyucikannya dengan memandikannya dengan air dan firman, supaya dengan demikian Ia menempatkan jemaat di hadapan diri-Nya dengan cemerlang tanpa cacat atau kerut atau yang serupa itu, tetapi supaya jemaat kudus dan tidak bercela (5:25-27). ${ }^{27}$

Manusia baru ini merupakan salah satu tema penting dalam teologi Paulus. Roma 6:6 mengatakan bahwa manusia lama telah turut disalibkan, agar jangan menghambakan diri lagi kepada dosa. Sementara Galatia 3:27 mengatakan bahwa identitas anak-anak Allah adalah mengenakan Kristus. Konsep ini semakin jelas ketika mencoba menyimak paralelisme bagian Efesus 4:22-24 dengan tulisan Paulus yang lain, dalam Kolose 3:9-10. Paulus menyatakan bahwa, "Allah...telah menghidupkan

\footnotetext{
${ }^{25}$ Ferguson, 138.

${ }^{26}$ George Eldon Ladd, Teologi Perjanjian Baru Jilid 2 (Bandung: Kalam Hidup, 1999), 248-249.

${ }^{27}$ Andrew T. Lincoln, The Theological of Ephesians dalam New Testament Thelogy The Theology of the Later Pauline letters (New York: Cambridge University Press, 2003), 121.
} 
orang percaya bersama-sama dengan Kristus, sekalipun orang percaya telah mati oleh kesalahan-kesalahan kita... dan di dalam Kristus Yesus Ia telah membangkitkan kita juga" (Ef 2:4-6).

Pengudusan definitif bukan hanya merupakan suatu pemutusan hubungan yang penting terhadap kuasa dosa yang memperbudak tetapi juga merupakan suatu kesatuan yang penting yang tidak dapat diubah dengan Kristus di dalam kebangkitan-Nya, suatu kesatuan yang menjadi sarana yang memampukan orang percaya hidup di dalam kehidupan yang baru (Rm. 6:4) dan kesatuan yang menyebabkan orang percaya menjadi ciptaan baru ( 2 Kor 5:17). Oleh karena itu, sebagai hasil dari pengudusan definitif atas diri orang percaya, maka sekarang berada di dalam Kristus harus menganggap diri kita "telah mati bagi dosa, tetapi ... hidup bagi Allah dalam Kristus Yesus" (Roma 6:11). ${ }^{28}$

\section{Ciptaan Baru Menurut Gambar Allah}

Manusia lama berada di bawah kuasa dunia yang jahat, maka manusia baru adalah bagian dari ciptaan baru dan hidup di dunia yang akan datang. Ini adalah karya Allah, bukan karya kita, namun fakta bahwa identitas baru ini dikenakan menunjukkan bahwa ciptaan baruNya dengan senang hati digunakan oleh orang percaya. Aktivitas ilahi dan respons manusia diimbangkan dengan cermat (bdg. Flp. 2:12-13), sedangkan frasa kesimpulan, "di dalam kebenaran dan kekudusan yang sesungguhnya," menunjukkan bahwa ada suatu implikasi etis signifikan pada pengenaan manusia baru ini. ${ }^{29}$

Ada tiga ciri khas penting dari manusia baru ini melalui frasa "diciptakan menurut kehendak Allah di dalam kebenaran dan kekudusan yang sebenarnya" yaitu: Pertama, suatu ciptaan baru yang disebabkan oleh Allah sendiri yang merujuk kepada aktivitas kreatif ilahi. Kedua, Allah bukan hanya pencipta dari karya ini; Ia juga pola atau teladan dari ciptaan baru tersebut. Ketiga, manusia baru diciptakan "serupa dengan Allah"; karena itu menjadi seperti Dia. Oleh karena itu sikap orang-orang percaya perlu konsisten dengan posisi dan status baru dalam Kristus. 30 Demikian Bruce menyatakan "constantly being renewed until it attains fulness of knowledge,"31 Artinya terus-menerus diperbarui sampai mencapai kepenuhan pengetahuan serupa dengan gambar-Nya.

\footnotetext{
${ }^{28}$ Hoekema, 283-284.

${ }^{29}$ O'Brien, 406.

${ }^{30}$ bdg. Ef. 2:10, "Karena kita ini buatan Allah, diciptakan dalam Kristus Yesus." Ciptaan baru dibuat "menurut kehendak Dia" (secara literal, "serupa dengan Allah"), artinya diciptakan "seperti Dia." Pada prinsipnya orang percaya sudah menjadi bagian dari ciptaan baru Allah (Ef. 2:10, 15; bdg. 2 Kor. 5:17; Gal. 6:15).

${ }^{31}$ F. F. Bruce, An Expanded Paraphrase of the Epistles of Paul (Exeter: Paternoster, 1965),
} 255. 
Ungkapan "diciptakan menurut kehendak Allah" memiliki kesejajaran dengan Kolose 3:10, "telah mengenakan manusia baru yang terus-menerus diperbarui untuk memperoleh pengetahuan yang benar menurut gambar Khaliknya." Manusia baru diperbarui menurut gambar Dia yang menciptakan, yaitu menurut gambar Allah. Manusia baru diciptakan "menurut" (dalam keserupaan) dengan Allah (Ef 4:24). Moule berpendapat bahwa manusia baru yang diciptakan oleh Allah dan berpusat pada Kristus tidak memandang diskriminasi, hitam dan putih, berpendidikan dan tidak berpendidikan, kaya atau pun miskin. ${ }^{32}$

Paulus juga menyebut orang percaya sebagai gambar Kristus: seperti telah mengenakan rupa duniawi, juga akan mengenakan rupa sorgawi (1 Kor 15:49; bdg. Rm 8:29: menjadi serupa dengan gambar Anak Allah; 2 Kor 3:18: diubah menjadi serupa dengan gambar-Nya dalam kemuliaan yang semakin besar). ${ }^{33}$ Orang percaya di dalam Kristus dibarui menjadi serupa dengan Kristus.

Manusia baru dideskripsikan sebagai diciptakan "menurut kehendak Allah di dalam kebenaran dan kekudusan yang sesungguhnya." Terdapat kontras yang jelas di sini antara kebenaran dan kekudusan yang menjadi ciri manusia baru dengan nafsu yang menyesatkan sebagai ciri manusia lama (ayat 22). Nafsu-nafsu berdosa menyesatkan, tidak pernah memberikan hal-hal baik yang tampaknya mereka janjikan, tetapi kebenaran dan kekudusan yang kita kejar sebagai manusia baru tidak akan pernah menyesatkan kita. ${ }^{34}$

Orang percaya menjadi serupa dengan Kristus merupakan aspek positif dari pengudusan. Paulus menulis, "Sebab semua orang yang dipilih-Nya dari semula, mereka juga ditentukan-Nya dari semula untuk menjadi serupa dengan gambaran Anak-Nya, supaya Ia, Anak-Nya itu, menjadi yang sulung di antara banyak saudara"35 Pengudusan merupakan suatu proses yang berlangsung sepanjang hidup dan baru terwujud secara penuh ketika kita melihat Tuhan. ${ }^{36}$

Berdasarkan Efesus 4:24 dan Kolose 3:24, maka gambar Allah dalam pengertian yang lebih sempit berarti berfungsinya manusia secara benar di dalam keharmonisan dengan kehendak Allah bagi dirinya. ${ }^{37}$ Berkhof menyimpulkan bahwa gambar dan rupa Allah ini mencakup dalam

${ }^{32}$ C. F. D. Moule, “The New Life' in Colossians 3:1-17," Review e Expositor 70-4 (Fall 1973): 481-493.

${ }^{33}$ Herman Ridderbos, Paulus Pemikiran Utama Theologinya (Surabaya: Penerbit Momentum, 2010), 235.

${ }^{34}$ Hoekema, 36.

${ }^{35}$ Roma 8:29; bdg. Flp. 3:10; 2 Kor. 3:18; 1 Yoh. 3:2.

${ }^{36}$ Henry C. Thiessen, Teologi Sistematika, cetakan kedua (Malang: Gandum Mas, 1993), 444.

${ }^{37}$ Hoekema, 92. 
integritas intelektual dan moral dari natur manusia yang terungkap dalam pengetahuan yang benar, kebenaran, dan kekudusan. ${ }^{38}$ Gambar Allah yang ada pada manusia baru adalah natur baru yang bersumber dari pribadi Kristus dan karya Allah dalam diri setiap orang percaya yang diciptakan menurut kehendak-Nya. Manusia baru tidak persis gambaran Kristus, tetapi sedang diubahkan menjadi gambar-Nya. Artinya, Allah Pencipta manusia baru adalah Pencipta orang percaya menjadi gambaran Kristus. $^{39}$

\section{Karya Roh Kudus}

Surat Efesus 4:23 menunjukkan tempat terjadinya pembaruan adalah "roh dan pikiranmu," suatu ungkapan tidak biasa yang tidak memiliki analogi dalam seluruh literature Yunani kuno. Di dalam Efesus istilah ini sama sekali tidak merujuk kepada roh manusia, sedangkan di seluruh surat ada suatu penekanan pada karya Roh Kudus dalam kehidupan orang percaya (Ef. 1:17; 3:16; 4:3; 5:18; 6:18). Konteks yang lebih dekat dengan ayat 24 mendukung rujukan kepada Roh ilahi. Dikatakan bahwa ketika Paulus mendorong para pembacanya untuk memiliki pikiran yang dibarui oleh Roh dan "mengenakan manusia baru," itu merupakan dua cara pengungkapan realitas yang sama, sedangkanperan "pembaruan budi" dalam etika Kristen (Rm. 12:2) memiliki penekanan yang sama. ${ }^{40}$

Karya Roh Kudus tidak hanya berlangsung ketika kita diselamatkan oleh anugerah-Nya, namun terus berlangsung di dalam hidup orang percaya. Karya Roh Kudus dalam kehidupan orang percaya adalah pengudusan yang berlangsung sepanjang hidup. Roh kudus memeteraikan orang percaya, dan Roh Kudus memampukan orang percaya untuk hidup kudus melalui ketaatan dengan pimpinan Roh Kudus, serta tidak mendukakan Roh Kudus (Ef. 4:30) yang adalah Pribadi yang juga adalah kebenaran dan kekudusan.

Hidup baru itu dialami di dalam alam roh. Ketika Paulus mengatakan bahwa di luar Kristus, manusia telah mati (Ef. 2:1), maka yang dimaksudkannya adalah mati secara rohani. Kematian roh manusia berarti tidak hidup dalam persekutuan dengan Allah disebut sebagai

\footnotetext{
${ }^{38}$ Louis Berkhof, Teologi Sistematika Volume 2 Doktrin Manusia (Surabaya: Penerbit Momentum, 2008), 56.

${ }^{39}$ Matthew A. Postiff, "A Theological And Exegetical Examination Of The "Old Man” Versus "New Man” Contrast," (Fellowship Bible Church, 2003), 22, diakses 12 Desember 2013, http://www.fellowshipbibleannarbor.org/BibleStudies/doctrinal/ColCh3Vv9tol0Exege sisPaper.pdf; Roma 8:29, "Sebab semua orang yang dipilih-Nya dari semula, mereka juga ditentukan-Nya dari semula untuk menjadi serupa dengan gambaran Anak-Nya, supaya Ia, Anak-Nya itu, menjadi yang sulung di antara banyak saudara."

${ }^{40}$ O'Brien, 404.
} 
manusia lama (Ef. 4:18). Fakta bahwa mereka telah dihidupkan berarti bahwa mereka telah dibawa masuk ke dalam persekutuan dengan Allah yang hidup. ${ }^{41}$ Ide yang sama dinyatakan di dalam ungkapan berjalan dalam kebaruan hidup (Rm. 6:4), berjalan menurut Roh (Rm. 8:4; Gal. 5:16). Berjalan menurut Roh berarti hidup setiap saat dan mengambil setiap keputusan di bawah tuntutan Roh yang mendiami setiap orang percaya. ${ }^{42}$ Paulus menasihatkan demikian, "Supaya kamu dibarui di dalam roh dan pikiranmu, dan mengenakan manusia baru" (Ef. 4:23-24). Roh Kudus yang menghidupkan roh yang telah mati dengan percaya kepada Tuhan melalui pengenaan manusia baru di dalam Kristus.

Paulus menasihatkan kepada jemaat pentingnya kesatuan dengan Kristus yaitu tidak jauh dari persekutuan dengan Kristus sebagai ciri manusia baru. Paulus mengajarkan pula bahwa orang-orang percaya ada "di dalam" Roh, sebagaimana dia pun telah berbicara mengenai keberadaan orang percaya di dalam Kristus. Orang percaya tidak "hidup di dalam daging, melainkan di dalam Roh" (Roma 8:9). ${ }^{43}$ Orang percaya bersatu dengan Roh Kudus dan Paulus menuliskan kepada jemaat Efesus pentingnya kesatuan tubuh Kristus, gereja (Ef. 4:1-16); orang percaya secara pribadi dengan Pribadi Kristus (Ef. 4:17-32) dan keluarga Kristen sebagai mempelai Kristus (Ef . 5:25-27).

Karya Roh Kudus yang lain adalah Roh Kudus memeteraikan orang percaya. Ada tiga bagian dalam Perjanjian Baru yang membicarakan tentang pemeteraian Roh Kudus. Yang pertama, Efesus 1:13 menambahkan bahwa kita dimeteraikan dengan Roh Kudus ketika kita percaya, dan sekali lagi, bahwa Roh Kudus itu adalah jaminan bagian kita sampai kita memperoleh seluruhnya (ayat 14). Kedua, Efesus 4:30 menyebutkan bahwa kita telah dimeteraikan oleh atau dengan Roh Kudus menjelang hari penyelamatan, dan ketiga, surat 2 Korintus 1:22, mengatakan bahwa Allah telah memeteraikan tanda milik-Nya atas kita dan yang memberikan Roh Kudus di dalam hati kita sebagai jaminan dari semua yang telah disediakan untuk kita. ${ }^{44}$

Surat Efesus 1:13 menggunakan kata kerja utama adalah "kamu dimeteraikan." Bentuk partisipel aorist yang menyertai kata tersebut ialah "percaya." Bentuk partisipel itu mungkin menyatakan suatu aksi yang mendahului aksi dalam kata kerja yang utama. Jika demikian percaya sebelum pemeteraian atau juga terjadi pada saat bersamaan. Penafsiran ini dapat diterima. Namun secara teologis, "percaya maupun pemeteraian" terjadi secara serentak. Apabila tidak, maka mungkin ada

\footnotetext{
${ }^{41}$ Ladd, 265.

${ }^{42}$ Ladd, 267.

${ }^{43}$ Leon Morris, Teologi Perjanjian Baru (Malang: Penerbit Gandum Mas, 1996), 103.

${ }^{44}$ Charles C. Ryrie, Teologi Dasar, cetakan ketiga (Yogyakarta: Penerbit ANDI, 1997), 133.
} 
orang percaya yang tidak dimeteraikan. ${ }^{45}$ Orang-orang percaya yang dimeteraikan oleh Roh Kudus supaya mereka jangan mendukakan Roh Kudus (Ef. 4:30). Roh Kudus adalah oknum Pribadi yang memiliki pikiran, perasaan dan kehendak. Perbuatan orang percaya yang memberikan kesempatan kepada iblis (4:27) berarti dia tidak bersatu dengan Roh Kudus. Orang percaya bersatu dengan Roh kudus karena "satu roh" (2:18;4:4), maka ketidaksatuan mendukakan Roh Kudus. ${ }^{46}$

Paulus berkata bahwa kita dimeteraikan dengan Roh Kudus menjelang hari penyelamatan. Pemeteraian Roh Kudus terjadi pada awal kehidupan Kristen (1:13), sebab Roh Kudus sendiri adalah meterai: kehadiran-Nya memeteraikan kita menjadi kepunyaan Allah (1:13). Pemeteraian dan hari keselamatan merujuk kepada awal dan akhir proses penebusan. Dan dia antara "awal dan akhir" itu kita bertumbuh kian menyerupai Kristus, dan berjaga-jaga supaya tidak mendukakan Roh Kudus. Setiap orang percaya yang dipenuhi Roh, ingin menyenangkan Roh Kudus, bukan untuk mendukakan-Nya. ${ }^{47}$

Roh Kudus adalah Pribadi Allah sendiri. Oleh karena itu, Paulus berkata "Janganlah kamu mendukakan Roh Kudus Allah." Roh Kudus dapat berdukacita apabila kita membenci seseorang. Sebab itu Paulus menasihatkan, "Segala kepahitan, kegeraman, kemarahan, pertikaian, dan fitnah hendaklah dibuang dari antara kamu" (4:31). ${ }^{48}$ Orang percaya yang tidak mendukakan Roh Kudus memiliki hidup yang kudus. Mereka hidup menurut Roh Kudus dipimpin oleh-Nya ke dalam semua kekudusan hidup. Kata-kata mereka selalu penuh kasih, tidak ada perkataan kotor yang keluar dari mulut mereka, sebaliknya mereka hanya berbicara perkataan baik untuk membangun. Orang percaya selalu berusaha supaya para pendengarnya beroleh kasih karunia. ${ }^{49}$

Roh Kudus yang menghidupkan manusia baru di dalam Kristus. Roh Kudus memiliki kuasa yang telah menciptakan langit dan bumi. Dialah yang mula-mula mengembuskan napas hidup ke dalam manusia dan memelihara kita dan "akan menghidupkan juga tubuhmu yang fana itu oleh Roh-Nya, yang diam di dalam kamu"? (Roma 8:11). ${ }^{50}$

Roh Kudus terus-menerus memperbarui tubuh yang fana yang telah dilahirbarukan oleh Dia sendiri di dalam Kristus. Roh Kudus memberi kita roh yang baru bagi orang percaya. Orang Kristen tidak pernah dibenarkan untuk berbuat dosa karena Roh yang berhuni dalam diri kita memberi kita kuasa untuk melawan dosa. Roh Kudus sedang

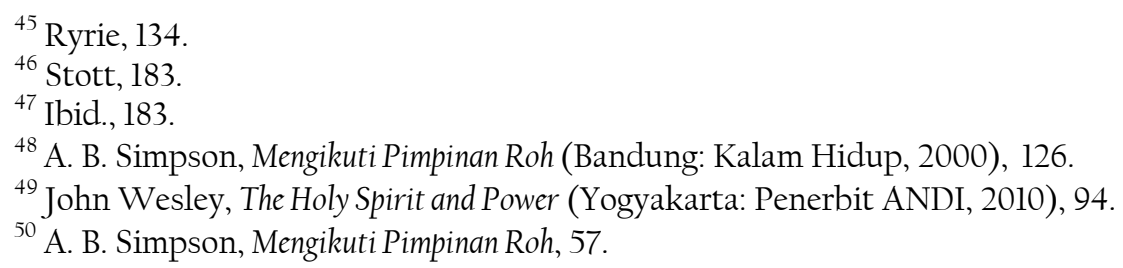


menyempurnakan kita dalam kekudusan ketika kita melakukan kehendak-Nya. $^{51}$

Roh Kudus tidak hanya menghidupkan melalui kelahiran baru, Ia juga memperbarui. Paulus berkata, "pada waktu itu Dia telah menyelamatkan kita, bukan karena perbuatan baik yang telah kita lakukan, tetapi karena rahmat-Nya oleh permandian kelahiran kembali dan oleh pembaruan yang dikerjakan oleh Roh Kudus" (Titus 3:5). Pembaruan berarti diri orang percaya menjadi baru. Suatu sifat/natur hidup yang baru. Roh Kudus memberi jati diri yang benar-benar baru dan memampukan orang percaya untuk melakukan pimpinan-Nya dan pekerjaan rohani.

\section{Implikasi Praktis Manusia Baru Di Dalam Kristus}

Paulus mencatat bahwa "kejahatan dan kebajikan yang dipilih oleh mereka dapat berdampak merusak atau meningkatkan kehidupan masyarakat," konsistensi ajaran dalam Efesus tentang kesatuan tubuh Kristus, di mana kita adalah "anggota satu sama lain" (4:25). Dia mengakui bahwa "karena itu" dari 4:25 menghubungkan ke bagian sebelumnya, yang membahas mengenai orang percaya baru posisi di dalam Kristus. Berikut ini adalah tindakan-tindakan praktis yang Paulus tuliskan dalam Efesus 4:25-32.

\section{Menyatakan Kebenaran}

Dalam menyatakan kebenaran maka manusia baru menyatakan perkataan benar, tindakan marah untuk menyatakan kebenaran, menyatakan kebenaran untuk tidak memberi kesempatan bagi iblis, perkataan yang membangun tubuh Kristus.

"Karena itu buanglah dusta dan berkatalah benar seorang kepada yang lain, karena kita adalah sesama anggota" (4:25). Kata "dusta" pseudos $^{52}$ yang berarti bohong, dusta, kebohongan. Warren Wiersbe mengatakan,

Perhatikan alasan yang diberikan oleh Paulus mengapa kita harus berkata benar: kita sama-sama anggota tubuh Kristus. Ia memberikan dorongan kepada kita untuk membangun tubuh Kristus dengan kasih (5:15). Sebagai sesama anggota tubuh Kristus, kita saling memengaruhi dan kita tidak dapat saling membangun terlepas dari kebenaran. Dosa pertama yang dihakimi dalam jemaat yang mula-mula adalah dusta (Kis. 5:1-11). ${ }^{53}$

\footnotetext{
${ }^{51}$ John Wesley, The Holy Spirit and Power, 184.

${ }^{52}$ Kata pseudos yang berarti lie, falsehood, lying (BMG Morphology, Word Analysis, s.v. "pseudos" In Bible Works Version 7).

${ }^{53}$ Wiersbe, Kaya di Dalam Kristus, 107.
} 
Paulus mengatakan bahwa sebagai manusia baru di dalam Kristus, maka segala dusta atau kebohongan di dalam jemaat harus dibuang dan sebagai gantinya berkata benar atau jujur terhadap yang lain sebagai anggota tubuh Kristus di dalam jemaat. Paulus tidak berbicara kepada sekelompok orang tertentu tentang berbohong, dia menunjuk kepada kebenaran yang harus berbicara dengan anggota tubuh: gereja. Jika gereja tidak dapat berbicara kebenaran satu sama lain, maka akan mustahil untuk bekerja secara kolektif untuk kebaikan Kerajaan Allah. ${ }^{54}$

Kata "marah" orgizesthe $e^{55}$ yang berarti to make angry (menjadi marah). Dalam Efesus 4:26, Paulus membuat komentar, "dalam kemarahan Anda jangan berbuat dosa." Dia tidak mengatakan tidak berbuat dosa, tapi jangan biarkan dosa berasal dari kemarahan ini. Vine mendefinisikan jenis kemarahan ini disebabkan oleh tindakan provokasi atau dibangkitkan. Hal ini dapat dilakukan melalui diri sendiri atau orang lain. Mazmur 4:5 menggunakan kutipan yang sama yang terlihat dalam ayat 26, "Biarlah kamu marah, tetapi jangan berbuat dosa," tetapi Mazmur melanjutkan dengan menunjukkan apa yang harus kamu lakukan dengan emosi itu, yaitu datang kepada Tuhan. Dosa bukanlah berasal dari tindakan marah tetapi lebih dari tindakan yang terjadi dalam kemarahan. ${ }^{56}$ Paulus menggunakan bentuk present, berarti marah adalah sebuah aksi yang dapat menimbulkan kekacauan atau melakukan hal-hal yang tidak dipertanggungjawabkan yang merupakan kebiasaan di dalam jemaat. Paulus sebagai figur yang patut diteladani memberikan suatu perintah imperative bahwa "apabila marah, janganlah kamu berbuat dosa" (4:26). Inilah sebabnya mengapa Bruce menafsirkan pandangan Paulus yang memberikan perintah untuk melakukan kontrol kemarahan seseorang, dan tidak membiarkan kemarahan ini berubah menjadi kebencian yang mengarah kepada kehancuran. ${ }^{57}$

Frasa janganlah matahari terbenam, sebelum padam amarahmu: Paulus mengingatkan orang terhadap bahaya menuruti amarah apalagi memupuk amarah, karena itu sama dengan membuka pintu dosa dan egoisme. Jika amarah (orgê) menjadi dendam (parorgismô, kata yang dipakai pada akhir ayat 26) kita harus berusaha memadamkannya, lalu mohon maaf atau mencari pendamaian dengan orang bersangkutan. ${ }^{58}$ Frasa "janganlah matahari terbenam, sebelum padam amarahmu" adalah

\footnotetext{
${ }^{54}$ F. F. Bruce, The Epistle to the Ephesians: A Verse-by-Verse Exposition (London: Pickering and Inglis LTD., 1961), 96.

55 "Kata orgizesthe verb imperative present passive 2nd person plural (BMG Morphology, Word Analysis, s.v. "orgizesthe" In Bible Works Version 7).

${ }^{56}$ W. E. Vine, Vine's Expository Dictionary of Old and New Testament Words: Super Value Edition (Carlisle: STL, 1997), s.v. "anger."

${ }^{57}$ F. F. Bruce, The Epistle to the Ephesians: A Verse-by-Verse Exposition, 96.

58 Stott, Efesus, 180-181.
} 
singgungan terhadap Ulangan 24:15. Kemarahan adalah emosi yang kuat yang harus ditangani dengan cepat. Apabila kemarahan terus berlangsung hingga keesokan harinya maka akan menjadi dosa dan di saat tidur pun kita mengalami kemarahan tersebut. ${ }^{59}$ Artinya setiap orang percaya boleh marah tetapi tujuan marah bukanlah melampiaskan amarah melainkan mendidik, menegur dengan kasih.

Frasa "janganlah beri kesempatan kepada iblis (4:27)." Bahaya lain yang diungkapkan oleh Paulus dari kemarahan adalah kesempatan bagi iblis. Maksudnya bahwa amarah yang terus menerus berlangsung akan memberikan tempat, peluang, atau kesempatan kepada iblis. Bahkan Luther dalam ungkapannya mengatakan bahwa "tidak ada orang di dunia ini yang lebih mampu melakukan kehancuran kecuali si pemfitnah dan penyebar berita bohong." ${ }^{60}$ Iblis cerdik memanfaatkan orang marah dengan menggodanya semakin membenci supaya bertindak lebih keji atau dendam atau memutuskan hubungan dengan orang lain.

Frasa "janganlah beri kesempatan kepada iblis" adalah kalimat present active imperative dengan negative particle yang biasanya berarti menghentikan suatu tindakan dalam proses. Kemarahan yang tidak saleh merupakan pembuka untuk serangan rohani bahkan kemarahan Ilahipun (lihat Yoh. 2:13-17; Mat. 21:12-13) harus ditangani dengan cepat (lihat Ef. 6:10-18). ${ }^{61}$ Kemarahan yang terus berlanjut akan menimbulkan dosa yang lain dan hal ini akan memberikan kesempatan bagi iblis mencuri damai sejahtera kita.

Paulus berkata, "janganlah ada perkataan kotor logos sapros. "Kotor" dalam Yunani adalah sapros yang berarti busuk, kata yang dipakai mengacu pada pohon atau buah yang busuk. ${ }^{62}$ Jadi maksud Paulus di sini adalah janganlah ada kata, pernyataan, atau percakapan yang busuk, buruk, atau tidak baik keluar dari mulutmu, sebab kata-kata demikian adalah dosa yang harus dibuang, tetapi pakailah perkataan yang baik. Dalam nasihat ini Paulus mengingat akan perkataan-perkataan kotor (busuk, buruk) yang banyak dipakai oleh orang-orang kafir dan sayang sekali juga dipakai oleh anggota-anggota jemaat. ${ }^{63}$ Oleh sebab itu, dengan tegas Paulus menuntut kepada mereka supaya perbuatanperbuatan dosa itu mereka buang atau mereka hentikan dan sebagai

${ }^{59}$ Bob Utley, "Paulus Terbelenggu, Injil Tak Terbelenggu: Surat-surat dari Penjara (Kolose, Efesus dan Filemon, Dan kemudian Filipi)," (Texas:Bible Lesson International, 1997), 165, diakses 18 Agustus 2014,

http://www.freebiblecommentary.org/pdf/VOL08_indonesia.pdf .168.

60 William Barclay, Pemahaman Alkitab Setiap Hari: Galatia-Efesus (Jakarta: BPK Gunung Mulia, 1983), 235.

${ }^{61}$ Bob Utley, "Paulus Terbelenggu, Injil Tak Terbelenggu: Surat-surat dari Penjara

(Kolose, Efesus dan Filemon, Dan kemudian Filipi)," 165.

${ }^{62}$ Stott, 182.

${ }^{63}$ Abineno, 162. 
ganti perkataan kotor itu, mereka memakai perkataan-perkataan yang baik yang membangun atau mendidik, di mana hal itu perlu, supaya dapat memberikan atau beroleh kasih karunia Allah bagi mereka yang mendengarkan.

\section{Bekerja untuk Memberkati}

Paulus berkata "orang yang mencuri, janganlah ia mencuri lagi (4:28)." Maksud Paulus di sini adalah bahwa orang yang mencuri janganlah ia mencuri lagi, tetapi lebih baik ia bekerja keras, berjerih payah atau berjuang mengerjakan pekerjaan yang baik. Namun, tidak hanya itu saja, Paulus menasihatkan bahwa sebagai sesama anggota tubuh Kristus jemaat harus saling membantu bagi orang-orang yang berkekurangan. Di sinilah sebenarnya arti manusia baru di dalam Kristus bahwa sebagai manusia baru janganlah ia mencuri, tetapi harus bekerja keras atau berjuang dan bukan hanya bekerja untuk diri sendiri tetapi membagikan sesuatu yaitu rela berkorban dengan memberi sesuatu yang dibutuhkan oleh orang lain. Stott menegaskan kembali bahwa tidak cukup hanya berhenti mencuri. Sang petobat harus bekerja sehingga ia dapat membiayai dirinya dan keluarga, bahkan memberi persembahan dan diakonia. ${ }^{64}$

Yudaisme sangat menghargai kerja keras, begitu juga orang Kristen mula-mula (bdg. 1 Tes. 4:11; 2 Tes. 3:10-12). Frasa "supaya ia dapat membagikan sesuatu kepada orang yang berkekurangan.” Bekerja tidak hanya merupakan kehendak Allah bagi umat manusia, tapi cara untuk berbagi dengan mereka yang membutuhkan. Orang percaya adalah penatalayan dari kemakmuran yang diberikan Allah (bdg. Ul. 8:11-20), bukan pemilik. Pemberian adalah barometer sejati dari kesehatan rohani kita (bdg. 2 Kor. 8-9). ${ }^{65}$ Paulus ingin pendengarnya tidak hanya berhenti mencuri, tetapi tetap berlatih kejujuran, diperkirakan bahwa beberapa pembaca adalah mantan budak. Hal ini menjadi godaan besar untuk menyelinap kembali ke gaya hidup lama. ${ }^{66}$

\section{Menyenangkan Roh Kudus}

"Mendukakan" dalam bahasa Yunani, lupeite ${ }^{67}$ yang berarti mendukakan, menyakiti, atau membuat sedih. Sebenarnya di sini Paulus memberikan suatu kesimpulan bahwa semua perbuatan-perbuatan

\footnotetext{
${ }^{64}$ Stott, 181.

65 Bob Utley, "Paulus Terbelenggu, Injil Tak Terbelenggu: Surat-surat dari Penjara (Kolose, Efesus dan Filemon, Dan kemudian Filipi)," 165.

${ }^{66}$ Hendriksen, Galatians and Ephesians, New Testament Commentary, 219.

${ }^{67}$ Kata lupeite verb imperative present active orang kedua jamak berasal dari kata lupeite yang berarti grieve, pain, to make sorrowful (mendukakan, menyakiti, atau membuat sedih) (BMG Morphology, Word Analysis, s.v. "lupeite" In Bible Works Version 7).
} 
negatif dalam ayat-ayat sebelumnya yang telah diuraikan dan perbuatan di dalam (ayat 31) yaitu kepahitan, kegeraman, pertikaian serta fitnah merupakan perbuatan yang dapat mendukakan Roh Kudus. Di sini Paulus menggunakan bentuk imperative present di mana ia ingin memberikan nasihat yang bersifat perintah supaya jemaat menghentikan kebiasaan-kebiasaan atau perbuatan-perbuatan yang tidak baik yang sebenarnya adalah mendukakan atau menyakiti Roh Kudus. Sebagai penjelasan tentang nasihat di atas yaitu supaya mereka (jemaat Efesus) "janganlah mendukakan Roh Kudus Allah, Paulus menambahkan "yang telah memeteraikan kamu menjelang hari penyelamatan." Roh Kuduslah yang telah menyegel mereka dan menetapkan mereka untuk masa depan Tuhan atau kedatangan Kristus yang kedua kali. Sebagai milik Kristus, merekalah meterai-Nya yang berarti provide with a seal (memeteraikan, mencap, mengokohkan). Maksudnya adalah Roh Kuduslah yang akan mengokohkan mereka menjelang penyelamatan Kristus. ${ }^{68}$ Billy Graham menambahkan bahwa peranan Roh Kudus adalah menerangi pikiran orang percaya, Roh Kudus tinggal di dalam tubuh orang percaya, Roh Kudus menghibur (Kis. 9:31), memimpin (Yoh. 16:13), menyucikan (Rm. 15:16), membantu dalam kelemahan (Roma 8:26), dan Roh Kudus menyertai kehidupan orang percaya. ${ }^{69}$

Frasa "Janganlah kamu mendukakan Roh Kudus Allah." Ini adalah sebuah present active imperative dengan negative particle yang biasanya berarti menghentikan suatu tindakan dalam proses. Hal ini mengungkapkan kebenaran bahwa Roh adalah suatu pribadi. Hal ini juga menunjukkan bahwa tindakan orang percaya menyebabkan rasa sakit kepada Roh Kudus (bdg. 1 Tes. 5:19; Yes. 63:10). Sasaran Roh untuk semua orang percaya adalah keserupaan dengan Kristus (bdg. 1:4;2:10; 4:13; Rom 8:28-29; Gal 4:19). ${ }^{70}$

Roh Kudus adalah oknum yang berkepribadian yang mutlak kudus, maka segala yang tidak kudus akan mendukakan Dia. Dan karena Ia "satu Roh" (2:18: 4:4), maka ketidaksatuan mendukakan Dia. Dan karena Ia adalah Roh kebenaran, melalui siapa Allah berbicara, maka Ia akan merasa terpukul bila kita menyalahgunakan kemampuan kita berbicara sebagaimana Paulus nasihatkan pada ayat-ayat sebelumnya (4:25-29). ${ }^{71}$

\footnotetext{
${ }^{68}$ Abineno, 165.

69 Billy Graham, Roh Kudus: Kuasa Allah Dalam Hidup Anda (Bandung: Lembaga Lietratur Baptis, 1978), 49-51.

${ }^{70}$ Bob Utley, "Paulus Terbelenggu, Injil Tak Terbelenggu: Surat-surat dari Penjara (Kolose, Efesus dan Filemon, Dan kemudian Filipi)," (Texas:Bible Lesson International, 1997), diakses 18 Agustus 2014,

http://www.freebiblecommentary.org/pdf/VOL08_indonesia.pdf .168.

${ }^{71}$ Stott, 183.
} 
Ayat 30, Paulus berkata bahwa kita "dimeteraikan dengan Roh Kudus menjelang hari penyelamatan." Pemeteraian dan hari keselamatan merujuk kepada awal dan akhir proses penebusan. Dan di antara "awal" dan "akhir" itu kita bertumbuh kepada keserupaan Kristus dan berjagajaga supaya tidak mendukakan Roh Kudus. Setiap orang percaya yang dipenuhi Roh ingin menyenangkan Roh Kudus, bukan mendukakanNya. $^{72}$

\section{Tindakan yang Benar (Ay. 31-32)}

Manusia baru harus mewujudnyatakan dalam tindakan yang benar. Nasihat Paulus berkata, "segala kepahitan, kegeraman, kemarahan, pertikaian, fitnah bahkan segala kejahatan, tanpa terkecuali bahwa semua bentuk kejahatan harus mereka buang (bdg. 5:3) seperti percabulan, rupa-rupa kecemaran, dan keserakahan disebut saja pun jangan di antara kamu. Namun, sebagai gantinya Paulus berkata "tetapi hendaklah kamu ramah, penuh kasih mesra yaitu penuh dengan kasih yang tulus dan sepenuh hati, saling mengampuni. ${ }^{73}$

\section{Kesimpulan}

Natur orang percaya menjadi manusia baru adalah sekali untuk selama-lamanya, namun proses untuk menjadi manusia baru adalah peristiwa yang terus-menerus diperbarui untuk serupa dengan gambarNya yang sesuai dengan kehendak-Nya. Faktanya orang percaya memiliki status manusia baru yang berarti tidak hidup lagi seperti manusia lama. Orang percaya menjalani kehidupan manusia baru.

Implikasi teologis pengenaan manusia baru dalam Kristus adalah: Proses menjalani kehidupan baru adalah suatu peritiwa di mana orang percaya terus-menerus diperbarui oleh Roh Kudus untuk menghasilkan kehidupan baru; Manusia baru adalah ciptaan yang baru yang serupa dengan gambar-Nya. Allah menciptakan manusia pada mulanya serupa dengan gambaran-Nya; Allah mempersatukan manusia baru di dalam Kristus. Di dalam Dia terjadi kebangkitan manusia baru; Manusia baru adalah karya Roh Kudus di dalam hidup orang percaya. Roh Kudus memeteraikan orang percaya dan mengerjakan keselamatan orang percaya menjadi manusia baru.

${ }^{72}$ Ibid., 183. Pemeteraian dengan Roh Kudus terjadi pada awal kehidupan Kristen (1:13), sebab Roh Kudus sendiri adalah meterai: kehadiran-Nya kita menjadi kepunyaan Allah (1:13).

${ }^{73}$ Abineno, 167. Maksudnya bahwa jemaat harus hidup saling mengampuni dengan murah hati, memberikan pengampunan satu dengan yang lain, bahkan dalam memaafkan orang lain harus disertai dengan kemurahan seperti Kristus dengan murah hati telah mengampuni segala dosa manusia. Pengampunan ini berdasar atas pengampunan yang Allah berikan kepada mereka dalam Kristus. 
Implikasi praktis pengenaan manusia baru dalam Kristus adalah tanggung jawab orang percaya yang memahami status baru di dalam Kristus untuk menyatakan kebenaran seperti berkata benar, melalui kemarahan yang benar, menjadi berkat bagi orang lain, tidak mendukakan Roh Kudus dengan membuang kejahatan dan mengenakan kasih di dalam Kristus.

\section{Kepustakaan}

Abineno, J. L. Ch. Tafsiran Alkitab Surat Efesus, Cet. kedelapan. Jakarta: BPK Gunung Mulia, 2003.

Barclay, William. Pemahaman Alkitab Setiap Hari: Galatia-Efesus. Jakarta: BPK Gunung Mulia, 1983.

Beauchamp, Lance T. "The Old and New Man in Ephesians 4:17-24."

Faculty Publications and Presentations, 2007. Diakses 12 Desember 2013. http://digitalcommons.liberty.edu/sor_fac_pubs/179.

Berkhof, L. Teologi Sistematika Volume 2 Doktrin Manusia. Surabaya: Penerbit Momentum, 2008.

Bruce, F. F. An Expanded Paraphrase of the Epistles of Paul. Exeter: Paternoster, 1965.

Bruce, F. F. The Epistle to the Ephesians: A Verse-by-Verse Exposition. London: Pickering and Inglis LTD., 1961.

Chafer, Lewis Sperry. Systematic Theology. Grand Rapids: Kregel, 1993.

Combs, William W. "Does The Believer Have One Nature Or Two?"

Detroit Baptist Seminary Journal 2 (Fall 1997): 81-103.

Darius dan Robi Panggarra, "Konsep Manusia Baru Berdasarkan Perspektif Paulus Dalam Efesus 4:17-32 Dan Implementasinya Dalam Kehidupan Orang Percaya," Jurnal Jaffray 1l, no. 2 (Oktober 2013).

Ferguson, Sinclair B. Kehidupan Kekristenan Sebuah Pengantar Doktrinal. Surabaya: Penerbit Momentum, 2007.

Graham, Billy. Roh Kudus: Kuasa Allah Dalam Hidup Anda. Bandung: Lembaga Lietratur Baptis, 1978.

Henry C. Thiessen, Teologi Sistematika, cet. kedua.Malang: Gandum Mas, 1993.

Hoekema, Anthony A. Diselamatkan Oleh Anugerah. Surabaya: Penerbit Momentum, 2010.

Ladd, George E. Teologi Perjanjian Baru Jilid 2. Bandung: Kalam Hidup, 1999.

Lincoln, Andrew T. The Theological of Ephesians dalam New Testament Thelogy The theology of the Later Pauline letters. New York: Cambridge University Press, 2003. 
Morris, L. The Epistle to the Romans in The Pillar New Testament Commentary. Grand Rapids: Eerdmans, 1988.

Morris, L. Teologi Perjanjian Baru. Malang: Penerbit Gandum Mas, 1996.

Moule, C. F. D. “The New Life' in Colossians 3:1-17," Review \& Expositor 70-4 (Fall 1973): 481-493.

O'Brien, Peter T. Surat Efesus. Surabaya: Penerbit Momentum, 2013.

Paxon, Ruth. The Wealth Walk and Warfare of The Christian. United Stated of Amerika: Fleming H. Revell Company, 1989.

Postiff, Matthew A. "A Theological And Exegetical Examination Of The "Old Man” Versus "New Man" Contrast." Fellowship Bible Church, 2003. Diakses 12 Desember 2013.

http://www.fellowshipbibleannarbor.org/BibleStudies/doctrinal/C olCh3Vv9tol0ExegesisPaper.pdf

Pratt, Richard L. Menaklukkan Segala Pikiran Kepada Kristus. Malang: Literatur Seminari Alkitab Asia Tenggara, 2003.

Ridderbos, H. Paulus Pemikiran Utama Theologinya. Surabaya: Penerbit Momentum, 2010.

Ryrie, Charles C. Teologi Dasar, cet. ketiga. Yogyakarta: Penerbit ANDI, 1997.

Showers, Renald. "The New Nature." Th.D. dissertation. Grace Theological Seminary, 1975.

Simpson, A. B. Mengikuti Pimpinan Roh. Bandung: Kalam Hidup, 2000.

Smith, Charles R. "Two Natures-Or One? An Attempt at Theological Clarification." Voice (Juli/Agustus 1983): 19-21.

Stott, John R. W. Efesus. Jakarta:Yayasan Komunikasi Bina Kasih, 2003.

Utley, Bob. "Paulus Terbelenggu, Injil Tak Terbelenggu: Surat-surat dari Penjara (Kolose, Efesus dan Filemon, Dan kemudian Filipi)."

Texas:Bible Lesson International, 1997. Diakses 18 Agustus 2014. http://www.freebiblecommentary.org/pdf/VOL08_indonesia.pdf .

Vine, W. E. Vine's Expository Dictionary of Old and New Testament Words: Super Value Edition. Carlisle: STL, 1997.

Wesley, John. The Holy Spirit and Power. Yogyakarta: Penerbit ANDI, 2010.

Wiersbe, Kaya di Dalam Kristus, 107.

William, Hendriksen. Galatians and Ephesians, New Testament Commentary. Grand Rapids: Baker, 1967. 